\title{
Islam dan Internet: Toleransi Beragama di Dunia Maya
}

\author{
Sandriansyah \\ Pascasarjana UIN Sunan Kalijaga, Yogyakarta, Indonesia \\ sandriansyahgejora@gmail.com
}

\begin{abstract}
Religious life is very dynamic, especially supported by increasingly advanced technological developments. Of course, the discussion of tolerance must follow the current technological developments because technological developments support it. With the existence of social media, people can gather through an Internet network called the virtual world, both from various countries and religions. This will create vulnerability to religious tolerance because the existence of social media conceivably allows people to show hatred towards other religions, to which according to them is against their religion. Relevant to the studied object, this research is included in the type of library research. Sources of data used in this literature are derived from the Internet, such as YouTube.
\end{abstract}

Keywords: Islam, Internet, Tolerance

\begin{abstract}
Abstrak
Kehidupan beragama sangat dinamis apalagi didukung dengan adanya perkembangan teknologi yang semakin maju. Tentu saja pembahasan tentang toleransi harus mengikuti perkembangan teknologi yang ada pada saat ini. Karena perkembangan teknologi mendukung dengan adanya media sosial, di mana orang dapat berkumpul melalui jaringan internet yang disebut dengan dunia maya (virtual), baik dari berbagai negara maupun agama. Hal ini akan membuat kerapuhan terhadap toleransi beragama karena dengan adanya media sosial yang memungkinkan orang dapat menunjukkan sikap kebencian terhadap agama lain yang menurutnya bertentangan dengan agamanya. Sesuai dengan objek kajiannya, penelitian ini termasuk dalam jenis penelitian kepustakaan (library research). Sumber data yang digunakan dalam kepustakaan ini berasal dari internet, seperti Youtube.
\end{abstract}

Kata Kunci: Islam, Internet, Toleransi

\section{Pendahuluan}

Islam adalah agama termuda Abraham, yang memiliki banyak kesamaan dengan agama Kristen dan Yahudi. Bahkan, sangat dekat dengan

FOKUS : Jurnal Kajian Keislaman dan Kemasyarakatan Vol. 5, No. 2, 2020

LPPM Institut Agama Islam Negeri (IAIN) Curup - Bengkulu

p-ISSN 2548-334X, e-ISSN 2548-3358

DOI: $10.29240 /$ jf.v5i2.1938 | p. 259-268 
tradisi, sehingga Al-Quran adalah wahyu dari Allah yang diturunkan kepada Nabi Muhammad (570-632 M), mengungkapkan bahwa Islam adalah pelengkap agama-agama sebelumnya, yang menjelaskan, melengkapi, dan memperkaya di kalangan agama-agama sebelumnya yang sering menyimpang dari jalan Allah. Nabi Muhammad mengajarkan Islam dengan kasih sayang sehingga mudah diterima oleh orang Arab yang memiliki sifat keras pada umumnya. ${ }^{1}$

Islam menjunjung tinggi persaudaraan bahkan dengan non-Muslim. Dalam Islam, ada banyak ajaran dan saran untuk menjaga hubungan baik dengan komunitas agama lain. ${ }^{2}$ Menghormati agama lain ini bukan berarti mendukung dan menyetujui praktik agama tersebut. Prinsip menghormati adalah sikap toleransi beragama tanpa adanya cacian dan hinaan. Ini sebagaimana tergambar dalam QS. Al-An'am ayat 108:

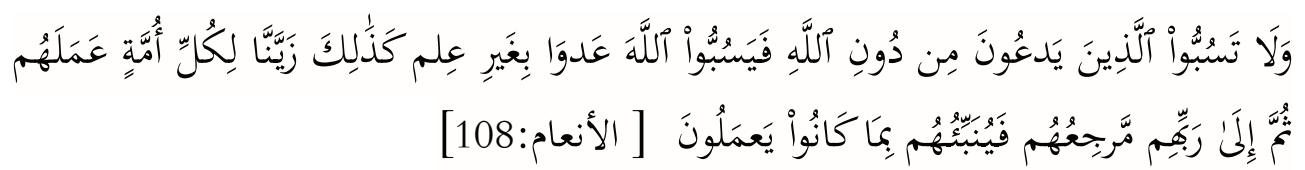

"Dan janganlah kamu memaki sesembahan yang mereka sembah selain Allah, karena mereka nanti akan memaki Allah dengan melampaui batas tanpa dasar pengetahuan. Demikianlah, Kami jadikan setiap umat menganggap baik pekerjaan mereka. Kemudian kepada Tuhan tempat kembali mereka, kemudian Dia akan memberitahukan kepada mereka apa yang telah mereka kerjakan."

Mengenai ayat di atas, diriwayatkan oleh al-Thabarî dari Qatâdah bahwa di zaman Nabi SAW Umat Islam mengejek berhala-berhala Kaum Kafir, maka ejekan ini gantian dibalas oleh mereka. Sebab itu, Allah melarang untuk mengejek tuhan mereka dikarenakan mereka orang-orang yang tidak berilmu. ${ }^{3}$ Dalam Asbâb al-Nuzûlnya, al-Wâhidî menceritakan ketika Umat Islam mengejek tuhan-tuhan Kaum Musyrik, terjadilah ultimatum terhadap Nabi SAW dan orang-orang Mukmin. Kaum Musyrik berkata: "Wahai Muhammad! Hanya ada dua pilihan, kamu tetap mencerca tuhan-tuhan kami, hlm. 158 .

${ }^{1}$ Deni Irawan, Islam dan Peace Building, Jurnal Religi, Vol. 10, No. 2, (Juli 2014),

${ }^{2}$ Harda Armayanto, Etika Al-Qur'an Terhadap Non-Muslim, Jurnal Tsaqafah, Vol. 9, No. 2, (November 2013), hlm. 291.

3 Al-Thabarî, Ibn Jarîr, Jâmi' Al-Bayân 'An Ta'wîl Ay Al-Qur'ân, 2001, hlm. 48. 
atau kami akan mencerca Tuhanmu?" Kemudian turunlah ayat di atas. ${ }^{4}$

Ayat ini secara eksplisit mengajarkan semua Muslim untuk dapat mempertahankan kesucian agama mereka, menciptakan rasa aman, dan memelihara hubungan yang harmonis antara komunitas agama. Manusia mudah terpancing ketika agama dan kepercayaan mereka disinggung. Ini adalah sifat manusia, apa pun posisi sosial dan tingkat pengetahuan. Ini karena agama berkembang di hati para penganutnya, sedangkan hati adalah sumber emosi. Berbeda dengan pengetahuan, yang mengandalkan akal dan pikiran. Seseorang dapat dengan mudah mengubah pendapat ilmiahnya, tetapi sangat sulit untuk mengubah keyakinannya meskipun kekeliruan bukti keyakinan yang ia pegang itu nyata dihadapannya. ${ }^{5}$

Dari prinsip menghormati ini, nantinya akan timbul sikap saling kerjasama antara komunitas beragama. Hal itu sesuai dengan firman Allah SWT yang artinya: Allah tidak melarang kamu untuk berbuat baik dan berlaku adil terhadap orang-orang yang tiada memerangimu karena agama dan tidak (pula) mengusir kamu dari negerimu. Sesungguhnya Allah menyukai orangorang yang berlaku adil. Sesungguhnya Allah hanya melarang kamu menjadikan sebagai kawanmu orang-orang yang memerangimu karena agama dan mengusir kamu dari negerimu, dan membantu (orang lain) untuk mengusirmu. Dan barangsiapa menjadikan mereka sebagai kawan, maka mereka itulah orang-orang yang zalim (QS. 60 [al-Mumtahanah]: 8-9).

Ayat di atas secara jelas menunjukkan bahwa Allah SWT tidak melarang Muslim untuk bekerja sama, saling membantu, dan berbuat baik kepada komunitas agama lain selama mereka tidak memusuhi, melawan, dan mengusir Muslim dari negara mereka. Berdasarkan ayat ini, Ibnu Katsir mengatakan bahwa Allah tidak melarang umat Islam untuk berbuat baik dan adil terhadap orang-orang kafir sementara mereka tidak memerangi umat Islam karena agama. Contohnya seperti berbuat baik kepada wanita dan orang lemah (dhu'afa). ${ }^{6}$ Saling menghormati dalam Islam tidak terbatas pada agama. Lebih luas dari itu, sikap hormat yang diajarkan oleh Allah dalam Al Qur'an

${ }^{4}$ Al-Wâhidî, Asbâb Al-Nuzûl, (Al-Dammâm: Dâr Al-Ishlâh, Cet. II, 1996), hlm. 221.

${ }^{5}$ M. Quraish Shihab, Tafsir Mishbah: Pesan, Kesan, dan Keserasian Al-Qur'an, Volume III, (Jakarta: Lentera Hati, Cet. Ii, 2009), hlm. 607.

${ }^{6}$ Ibn Katsîr, Tafsîr Al-Qur'ân Al- 'Azîm, Jilid II, (Giza: Mu'assasah QordhobaMaktabah Aulâd Al-Syaikh Li Al-Turâts, Cet. I, 2000), hlm. 517. 
juga mencakup ras, etnis, dan sebagainya.

Dari penjelasan di atas, artikel ini mencoba mengulas tentang toleransi beragama yang terdapat di internet. Di mana Islam sebagai agama yang menginginkan pembangunan perdamaian. Maka dari itu, dalam Islam diajarkan untuk menerapkan sikap toleransi beragama dalam hal apapun termasuk dalam dunia maya atau intenet. Di internet memberikan kebebasan berekspresi yang tidak dapat terbatas bagi siapapun, sehingga toleransi antar umat beragama di dunia maya perlu adanya aturan yang dapat mengarahkan agar tidak terjadi intoleran terhadap agama lain atau selain agamanya. Internet juga telah menjadi salah satu sumber daya informasi yang paling potensial untuk membuat sistem kehidupan lebih mudah. Bayangkan saja, kehadiran internet telah mampu melahirkan sistem kehidupan baru lainnya, atau disebut dunia maya (dunia virtual). Hal ini juga diungkapkan oleh Talika bahwa dunia maya memiliki kesamaan yang sangat jelas dengan kehidupan nyata. Apa yang Anda lakukan di dunia nyata, saat ini kita juga bisa melakukannya di dunia maya. ${ }^{7}$

Dari dua pernyataan di atas, antara Islam dan internet dapat diambil kesimpulan bahwasannya Islam adalah agama yang di sampaikan oleh nabi Muhammad saw untuk menyempurnakan agama-agama sebelumnya dan intenet adalah hasil temuan dari kemajuan ilmu pengetahuan manusia yang salah satu fungsinya adalah memudahkan manusia yang menggunakan internet dalam menggali informasi yang di cari, sedangkan penjelasan tentang Islam dan internet adalah penjelasan tentang bagaimana cerminan Islam yang berada di dunia maya. Tujuan dari penulisan ini adalah untuk melihat toleransi beragama di dunia maya.

Fokus penelitian ini yaitu untuk melihat toleransi beragama di dunia maya. Artikel ini menggunakan pendekatan kualitatif dengan metode kepustakaan (library research). Studi pustaka atau kepustakaan merupakan sekelompok kegiatan yang berhubungan dengan metode pengumpulan data pustaka, membaca, dan mencatat serta mengolah bahan penelitian. ${ }^{8}$ Penelitian berbasis literatur juga dapat diartikan sebagai bentuk penelitian yang

${ }^{7}$ Febi Trafena Talika, Manfaat Internet Sebagai Media Komunikasi Bagi Remaja di Desa Air Mangga Kecamatan Laiwui Kabupaten Halmahera Selatan, E-Journal Acta Diurna Volume V. No.1, (Tahun 2016), hlm. 2.

${ }^{8}$ Zed Mestika, Metode Penelitian Kepustakaan, (Jakarta: Yayasan Obor Indonesia, 2003), hlm. 3. 
menggunakan literatur sebagai objek kajian. Sumber data yang digunakan dalam kepustakaan ini berasal dari internet, diantaranya seperti media sosial, youtube, atau berita online. Teknik pengumpulan data dalam artikel ini dilakukan dengan menelaah atau mengeksplorasi beberapa media sosial maupun youtube serta sumber-sumber data atau informasi lainnya yang dianggap relevan dengan penelitian ini.

\section{Toleransi Beragama Di Dunia Maya}

Agama dan kepercayaan yang berbeda adalah bentuk keragaman. Toleransi antara komunitas agama dirasakan perlu diperkuat lagi di sendi kehidupan bangsa dan negara. Toleransi merupakan kemampuan untuk menghormati sifat, kepercayaan, dan perilaku orang lain. Dalam literatur agama Islam, toleransi disebut tasamuh yang dipahami sebagai sifat atau sikap menghormati, mengizinkan, atau memungkinkan pendirian (pandangan) orang lain yang bertentangan dengan pandangan kita.

Kolaborasi antara komunitas agama sangat penting dalam memperkuat persatuan dan kesatuan. Dalam keragaman agama, yang muncul dalam masyarakat multikultural yang memiliki sistem pemerintahan republik atau monarki, perbedaan sering memicu munculnya berbagai hambatan dalam kohesi sosial. Terdapat dua jenis toleransi beragama diantaranya: toleransi agama pasif, yaitu sikap menerima perbedaan sebagai sesuatu yang faktual. Selanjutnya, toleransi beragama aktif, yaitu toleransi yang melibatkan diri sendiri dengan orang lain di tengah perbedaan dan keberagaman.

Keberagaman yang dimiliki menjadikan masyarakat secara alami hidup saling berdampingan didalam perbedaan. seharusnya semua itu bukanlah menjadi penghalang apalagi menjadi sebuah ancaman bagi keutuhan. Perbedaan yang ada dalam masyarakat justru menjadi penguat dalam hidup berbangsa dan bernegara. Multikululturalisme bukanlah sesuatu yang baru dalam topik pembicaraan. Pentingnya pengetahuan mengenai multikulturalisme seperti yang dicontohkan adalah memasukan pendidikan multikulturalisme didalam sistem pendidikan. ${ }^{9}$

Seiring berkembangnya teknologi dan informasi sampai ditemukannya internet, maka sikap toleransi juga akan berdampak terhadap dunia maya. Sehingga dunia maya (virtual) telah menjadi media potensial untuk

\footnotetext{
${ }^{9}$ Ibid., hlm. 71.
} 
mentransformasikan nilai-nilai toleran. Namun di sisi lain, dinamika dunia maya diakui juga menciptakan dilema. Sisi positif dan negatif dari konten dan efeknya hampir sekuat keberadaannya. Faktor utama yang bisa dikendalikan adalah pelakunya dan aturan yang sesuai dengan ruang lingkup.

Dunia maya adalah gudang informasi yang sangat melimpah untuk saat ini, akan tetapi tidak semua informasi yang disampaikan di dunia maya dapat dipertanggung jawabkan akan kebenarannya. Dan seharusnya sebagai pengguna intenet kita seharunya meneliti dan menggali informasi sebanyakbanyaknya supaya tidak salah dalam menerima dan menerapkan apa yang telah kita pelajari di dunia maya.

Istilah toleransi berasal dari bahasa Latin dari kata "Tolerare" yang berarti sabar membiarkan sesuatu. Toleransi umumnya adalah perilaku sikap manusia yang tidak menyimpang dari aturan, di mana seseorang menghargai atau menghormati setiap tindakan yang diambil oleh orang lain. ${ }^{10}$ Toleransi berperan untuk membentuk hubungan antara komunitas agama, terutama toleransi sosial diwujudkan di antara warga negara. Sikap toleransi sosial berkembang di antara warga negara mendorong rasa saling menghargai, menghormati dan dapat bekerja bersama antara penganut agama yang berbeda disebabkan oleh kesadaran akan peran masing-masing individu sebagai bagian dari masyarakat majemuk. Hal tersebut sejalan dengan pendapat Eko Digdoyo yang menyatakan bahwa toleransi adalah kebajikan moral yang berharga juga dapat mengurangi kebencian, kekerasan dan kefanatikan. Dengan toleransi juga, kita dapat memperlakukan orang lain dengan kebaikan, rasa hormat, dan pengertian. ${ }^{11}$

Toleransi antar umat beragama adalah langkah paling tepat guna menjaga kerukunan antar umat beragama, yang berarti bahwa setiap komunitas agama memungkinkan dan memelihara suasana yang kondusif bagi komunitas agama lain untuk melaksanakan ibadah dan ajaran agama mereka tanpa dihalangi. ${ }^{12}$ Toleransi kerap menjadi perbincangan yang sering

${ }^{10}$ Eko Digdoyo, Kajian Isu Toleransi Beragama, Budaya, dan Tanggung Jawab Sosial Media, Jurnal Pancasila dan Kewarganegaraan, Vol. 3, No. 1, (Januari 2018), hlm. 46.

11 Yogi Nugraha, Yudi Firmansyah, Karakter Toleransi Beragama dalam Sudut Pandang Generasi Milenial, Jurnal Moral Kemasyarakatan, Vol. 4 No. 2, (Tahun 2019), hlm. 70.

12 Suryan A. Jamrah, Toleransi Antarumat Beragama: Perspektif Islam, Jurnal Ushuluddin, Vol. 23 No. 2, (Desember 2015), hlm. 186. 
menyelimuti ketika membahas tentang keagamaan, karena menjadi sebuah acuan agar dapat menghargai dan menghormati agama dan keyakinan yang berbeda.

Berdasarkan pengertian di atas maka toleransi beragama dapat diterapkan di dunia maya (virtual), akan tetapi ruang lingkup di dunia maya terlalu luas. Sehingga perlu ada aturan yang mengatur terhadap toleransi beragama yang diterapkan di dunia maya dan dapat menerapkan perilaku yang baik pada umat beragama. Maka dari itu terciptalah kebajikan moral yang berharga.

Sebagai bentuk toleransi beragama yang diterapkan di dunia maya belum sepenuhnya berjalan, karena disebabkan oleh adanya orang-orang atau oknum-oknum yang memanfaatkan internet untuk menunjukkan sikap intoleran terhadap agama yang berbeda dengannya. Hal ini dapat dilihat dari tayangan video youtube yang berdurasi 3 menit 41 detik yang dapat ditonton pada link berikut (https://youtu.be/DbCo-Mpdo9M). Dalam video tersebut ada seorang laki-laki yang agamanya tidak diketahui tetapi orang tersebut menghina agama. Dia membicarakan tentang surga dan neraka, bahwasannya itu adalah suatu kebohongan yang tidak dapat dipercayai. Karena menurutnya ajaran tersebut adalah ajaran khayalan yang mengandung kebohongan.

Tayangan youtube selanjutnya yaitu berdurasi 5 menit 22 detik yang dapat ditonton pada link berikut (https://youtu.be/HfMrKl-1_gI). Dalam video tersebut ada seorang laki-laki yang menghina Tuhan dari agama Kristen, Budha, dan Hindu yang disampaikan melalui lagu versinya. Di dalam lagu itu terdapat lirik yang berisi tentang ejekan-ejekan terhadap Tuhan dari ketiga agama tersebut.

Selanjutnya yaitu tayangan youtube berdurasi 8 menit 43 detik yang dapat ditonton pada link (https://youtu.be/zpHxo40A33w). Dalam video tersebut ada seorang laki-laki yang melecehkan ayat suci Al Qur'an dan melecehkan adzan. Dia berbicara dengan bercanda yang mengungkapkan bahwa ayat-ayat dalam surat Ad Dhuha itu menurutnya tidak penting. Selain itu dia juga melecehkan adzan dengan melantunkan arti dari adzan itu sendiri tetapi arti tersebut diganti versinya yang menunjukkan pelecehan terhadap agama Islam. Sehingga mengakibatkan kemarahan beberapa umat Islam mendatangi laki-laki tersebut untuk dilaporkan kepada pihak yang berwajib. 
Dari beberapa video di atas menunjukkan bahwasannya toleransi beragama di dunia maya yang diupload melalui youtube terlihat betapa bebasnya seseorang ketika menyampaikan kebenciannya terhadap agama lain. Padahal ungkapan-ungkapan tersebut sebaiknya tidak perlu dilakukan, karena dapat menyakiti bagi penganut agama yang dihinanya. Hal ini tidak sependapat dengan sikap toleransi beragama seperti yang telah dipaparkan di atas. Dilain sisi hal tersebut juga sangat bertentangan dengan ayat Al Qur'an dalam surat Al Kafirun ayat 6:

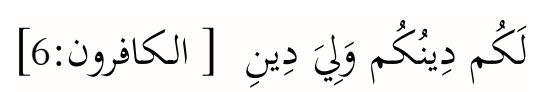

"untukmu agamamu, dan untukkulah, agamaku." (Q.S. Al Kaafiruun: 6)

Maka dari itu, sudah sepatutnya untuk senantiasa menghargai dan bersikap bijak dalam menghadapi perbedaan, terlebih jika berkaitan dengan masalah keyakinan seseorang. Memang tak jarang perbedaan keyakinan menjadi akar terjadinya perdebatan, bahkan konflik dan peperangan. Tidak sedikit pula pemeluk agama merasa dirinya yang terbaik lalu menghina Tuhan atau ajaran dari agama lain. Sehingga hal ini kerap menimbulkan permusuhan diantara umat beragama. Padahal sebenarnya hal tersebut merupakan perbuatan yang sangat tercela dan sangat dilarang menurut pandangan Islam sama halnya dengan hukum melecehkan agama dalam Islam.

\section{Kesimpulan}

Sikap toleransi dalam kehidupan beragama dengan menghormati dan menjaga hak dan kewajiban masing-masing, dengan meningkatkan kesadaran akan pentingnya toleransi dalam kehidupan beragama, dapat diharapkan untuk membangun hubungan yang harmonis antara umat beragama yang akan membawa kemakmuran bagi masyarakat dan mempercepat pembangunan perdamaian.

Agama sejatinya sudah menanamkan sikap toleransi antar agama agar tidak saling mengganggu dan mengusik agama lain. Akan tetapi yang menjadi permasalahnya adalah sikap intoleran terjadi karena kurangnya pemahaman masyarakat dalam memahami sikap toleransi itu sendiri, dengan perkembangan zaman dan terciptanya internet membuat intoleransi semakin menjadi-jadi, dan sikap intoleran yang dibawa ke dunia maya membuat sikap balasan yang berakibat sikap toleran antar agama menjadi rusak dan memiliki dampak yang lebih besar jika tidak ditanggapi dengan serius. Dalam hal ini 
tentunya membutuhkan aturan dalam dunia maya (virtual) yang mengatur tentang toleransi antar umat beragama.

\section{Daftar Pustaka}

Al-Thabarî, Ibn Jarîr. Jâmi’ Al-Bayân ‘An Ta’wîl Ay Al-Qur’ân. 2001.

Al-Wâhidî. 1996. Asbâb Al-Nuzûl. Al-Dammâm: Dâr Al-Ishlâh, Cet. II, 1996.

Deni Irawan. Islam dan Peace Building, Jurnal Religi, Vol. 10, No. 2, (Juli 2014).

Eko Digdoyo. Kajian Isu Toleransi Beragama, Budaya, dan Tanggung Jawab Sosial Media. Jurnal Pancasila dan Kewarganegaraan, Vol. 3, No. 1, (Januari 2018).

Febi Trafena Talika. Manfaat Internet Sebagai Media Komunikasi Bagi Remaja di Desa Air Mangga Kecamatan Laiwui Kabupaten Halmahera Selatan. E-Journal Acta Diurna, Volume. V, No.1, (Tahun 2016).

Harda Armayanto. Etika Al-Qur'an Terhadap Non-Muslim. Jurnal Tsaqafah, Vol. 9, No. 2, (November 2013).

Ibn Katsîr. Tafsîr Al-Qur'ân Al- 'Azîm. Jilid II. Giza: Mu'assasah QordhobaMaktabah Aulâd Al-Syaikh Li Al-Turâts, Cet. I. 2000.

Jonathan Sarwono. Metode Penelitian Kuantitatif dan Kualitatif. Yogyakarta: Graha Ilmu. 2006.

M. Quraish Shihab. Tafsir Mishbah: Pesan, Kesan, dan Keserasian Al-Qur'an, Volume III. Jakarta: Lentera Hati, Cet. II. 2009.

Suryan A. Jamrah, Toleransi Antarumat Beragama: Perspektif Islam, Jurnal Ushuluddin, Vol. 23, No. 2, (Desember 2015).

Tjiptohadi Sawarjuwono dan Agustine Prihatin Kadir, Intellectual Capital: Perlakuan, Pengukuran dan Pelaporan (Sebuah Library Research), Jurnal Akuntansi \& Keuangan Vol. 5, No. 1, Mei 2003.

Yogi Nugraha, Yudi Firmansyah, Karakter Toleransi Beragama dalam Sudut Pandang Generasi Milenial, Jurnal Moral Kemasyarakatan, Vol. 4 No. 2 (Tahun 2019). 
268 | FOKUS : Jurnal Kajian Keislaman dan Kemasyarakatan Vol. 5, No. 2, 2020

Halaman ini dikosongkan 